\title{
Characteristics of tropical cyclones making landfall on the Pacific coast of Mexico: 1970-2010
}

\author{
L. M. FARFÁN \\ Centro de Investigación Cientifica y de Educación Superior de Ensenada, Unidad La Paz, La Paz, Baja \\ California Sur, México \\ Corresponding author; e-mail: farfan@cicese.mx
}

\begin{abstract}
E. J. ALFARO
Centro de Investigaciones Geofísicas, Escuela de Física, Centro de Investigaciones en Ciencias del Mar y Limnología, Universidad de Costa Rica, San José, Costa Rica
\end{abstract}

T. CAVAZOS

Centro de Investigación Cientifica y de Educación Superior de Ensenada, Departamento de Oceanografía Física, Ensenada, Baja California, México

Received October 15, 2011; accepted September 14, 2012

\begin{abstract}
RESUMEN
Este estudio evalúa los impactos de los ciclones tropicales (CT) que tocaron tierra en áreas pobladas a lo largo de la costa del Pacífico mexicano. El periodo de interés abarca de 1970 a 2010 y se utiliza una base de datos internacional de desastres para identificar dichos impactos. Se registraron más de 30 eventos durante el periodo de referencia, de los cuales se examinan los 25 que acumularon mayor precipitación, así como los 10 que causaron mayores daños a la población afectada, que en estos casos varió de 20000 a más de 800000 habitantes. Vientos fuertes y precipitación intensa en periodos de uno a tres días se asociaron con daños materiales y pérdida de vidas humanas. Los resultados del estudio indican que las acumulaciones excesivas de lluvia y su intensidad diaria son elementos importantes vinculados con la ocurrencia de desastres en áreas densamente pobladas. Seis de los primeros $10 \mathrm{CT}$ asociados con los mayores desastres ocurrieron en condiciones de El Niño y tres en condiciones neutrales; sin embargo, al examinar los 25 CT asociados con la precipitación acumulada, se observó que 10 de éstos ocurrieron en condiciones de El Niño y 10 en condiciones neutrales. Tres casos ocurridos en eventos correspondientes a El Niño (Liza en 1976, Pauline en 1997 y Lane en 2006) se documentaron con más detalle debido a que afectaron áreas con densidades poblacionales diferentes en las costas del sur y noroeste de México.
\end{abstract}

\begin{abstract}
This study evaluates impacts from tropical cyclone (TC) landfalls on populated areas located along the Pacific Ocean coast of Mexico. The period of interest is from 1970 through 2010 and an international disaster database is used to identify the impact from the landfalling TCs. More than 30 landfall events occurred during the period; we examined the top 25 TCs based on rainfall accumulation, as well as the top 10 TC-related disasters based on the affected population. Each event resulted in affected population from 20000 to more than 800000 . Strong winds and heavy rainfall, during periods of one to three
\end{abstract}


days, are associated with property damage and loss of lives. Our results indicate that excessive rainfall accumulations and daily rates, over highly populated areas, are important elements associated with the occurrence of disasters. Six of the top 10 TC-related disasters occurred during El Niño and three during neutral conditions; however, looking at the top 25 events, 10 occurred during El Niño and 10 during neutral conditions. Three case studies that occurred during El Niño events (Liza in 1976, Pauline in 1997, and Lane in 2006) are documented in more detail as they affected areas with different population densities in the southern and northwestern coasts of Mexico.

Keywords: Tropical cyclones, eastern Pacific Ocean, Mexico, coastal impact.

\section{Introduction}

Mexico is located within tropical and subtropical latitudes, extending from 14 to $33^{\circ} \mathrm{N}$. A significant portion of the country has elevations over $1000 \mathrm{~m}$ asl while coastal plains contribute to one third of the total area. These are relevant features that determine the spatial distribution of air temperature, low-level winds, and precipitation (Mosiño and García, 1974). During the warm season, from June through October, easterly flow is present at low and middle levels and tropical cyclones (TCs) play a significant role among the atmospheric weather systems. These systems originate from the western Atlantic or the eastern Pacific basins to bring significant moisture and convection to Mexico's coasts and inland regions. While most of the TCs develop over the open ocean some of them move close to the continent to provide periods of strong winds and heavy rainfall; eventually, their presence over land may cause property damage as well as loss of human lives.

Figure 1 shows the landfall distribution of TCs that moved onshore through the Pacific coastline during the period 1970-2010. The highest frequencies are located over the states of Baja California Sur $\left(\mathrm{BCS}, 23-28^{\circ} \mathrm{N}\right)$ and Sinaloa $\left(22.5-26.5^{\circ} \mathrm{N}\right)$, both in northwestern Mexico. The third largest frequency is in the state of Oaxaca $\left(94-100^{\circ} \mathrm{W}\right)$, in southern Mexico. In general, the spatial and temporal distribution as well as the characteristics of intensity are consistent with results from Jáuregui (2003). The Mexican coast has a length of more than $10000 \mathrm{~km}$ and the Pacific (or west) coast has more than $50 \%$ of such length. Eleven states comprise this coastline and their geographical distribution is also shown in Figure 1. There are wide mountain ranges with maximum elevations over $2000 \mathrm{~m}$ and oriented in a direction parallel to the coast, known as the Sierra Madre Occidental $\left(105-110^{\circ} \mathrm{W}\right)$ and Sierra Madre del Sur $\left(105-95^{\circ} \mathrm{W}\right.$, south of $\left.20^{\circ} \mathrm{N}\right)$. As a complementary display, the bottom panel of Figure 1 shows the number of TCs that have their circulation center close $(<30 \mathrm{~km})$ to the coast. Again, the latitudes covering BCS and Sinaloa have the highest frequency (above 20 occurrences) and a secondary maximum is located along the coastal areas from Oaxaca through Jalisco.

Data from population surveys, provided by the Mexican agency for geographical information (INEGI, 2011), are used to determine the spatial distribution and population density. A brief decadal summary of the population of the west coast states is shown in Figure 2. Since 1970, the population has increased from almost 15 million inhabitants to more than 34 million in 2010. Nearly $30 \%$ of the whole country population is in the Pacific coast states and this proportion has remained almost constant throughout the last few decades. An important fact is that the population is concentrated in relatively small and well-defined areas; that is, a considerable fraction (about 40\%) lives in settlements of more than 100000 people. Closer examination of the available data indicates that most of the west coast population (70-75\%) also concentrates along the region bounded by the states of Chiapas to Jalisco where, during the study period, the population density has increased 


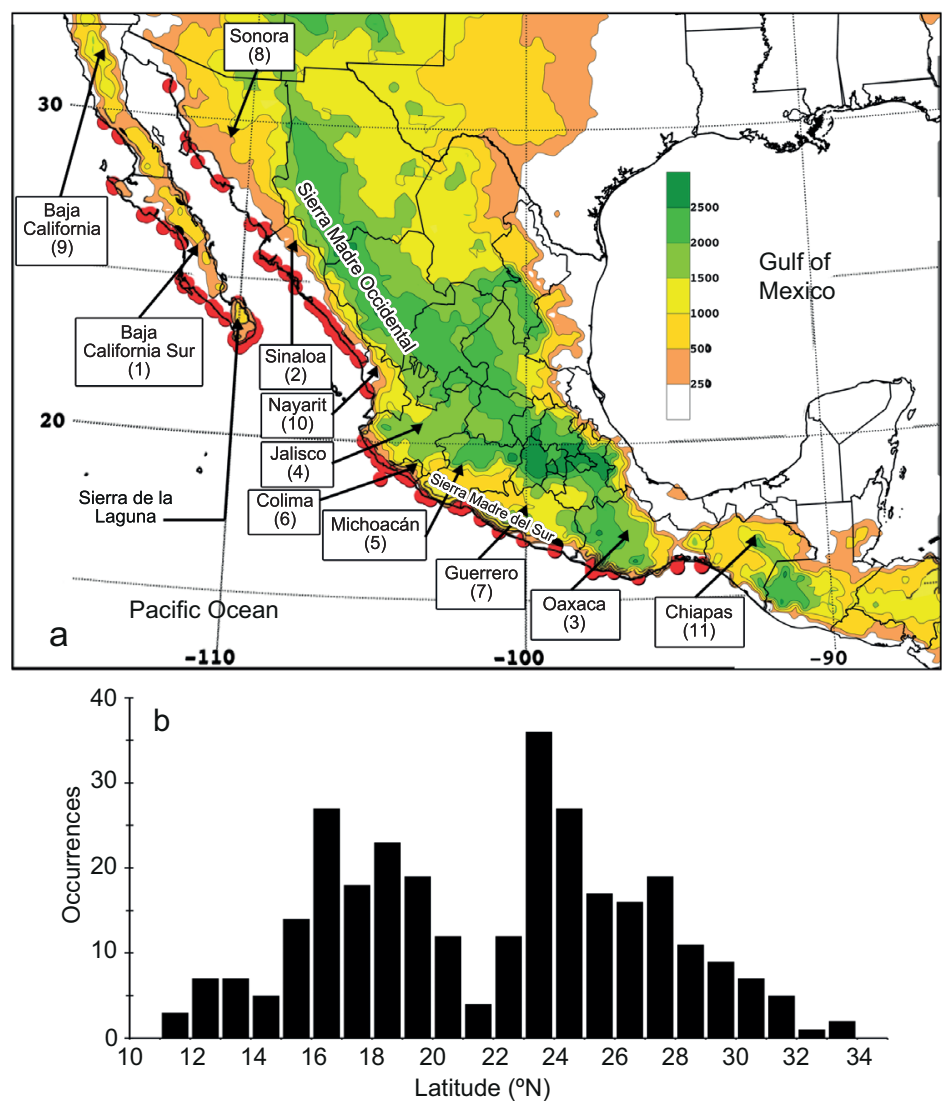

Fig. 1. (a) Topography of Mexico with terrain elevations (m) shaded. Dots indicate the location of more than 100 landfall sites during the period 1970-2010, from tropical cyclones in the eastern Pacific basin. The state distribution along the west coast is indicated by the ranking given in parentheses. Ranking 1 is assigned to the state receiving most landfalls (Baja California Sur) and increases to 11 for the least affected (Chiapas). (b) Number of tropical cyclone positions, classified by latitude, found in a radius of less than $30 \mathrm{~km}$ from any point of the Pacific coast of Mexico.

from an average of 32 to 74 inhabitants $/ \mathrm{km}^{2}$. In contrast, reduced densities in the northwest have been scattered among a few states; particularly, BCS has the lowest density ranging from less than 2 inhabitants $/ \mathrm{km}^{2}$ in 1970 to more than 8 inhabitants $/ \mathrm{km}^{2}$ in 2010 . This suggests that upon a TC landfall, major differences should be expected between the impacts from tracks over southern Mexico versus those moving into the northwest.

Our goal is to document the impacts from landfalling TCs that originated in the eastern Pacific basin during the period 1970-2010. The primary objective is to determine, based on a disaster database, the landfall events that caused major impacts on the Mexican population. In particular, we wish to document the general features of the TC upon arrival to land with respect to heavy rainfall, as well as to identify the synoptic-scale conditions that characterized the atmospheric environment in which these TCs are embedded. 


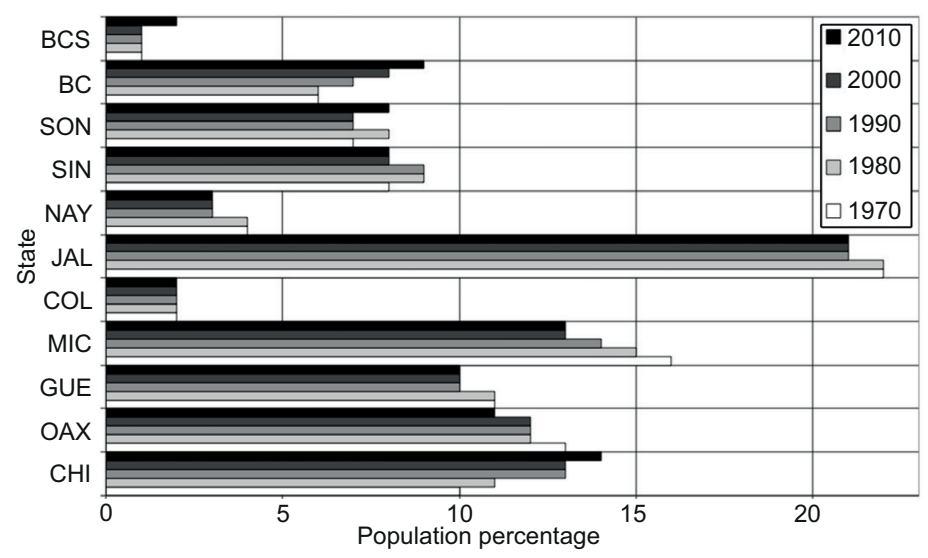

Fig. 2. Distribution (percentage, horizontal axis) of the population among the Pacific coast states of Mexico from 1970 through 2010. The percentage is with respect to the population in the above states. Data source: INEGI, 2011.

BCS: Baja California Sur; BC: Baja California; SON: Sonora; SIN: Sinaloa, NAY: Nayarit; JAL: Jalisco; COL: Colima; MIC: Michoacán; GUE: Guerrero; OAX: Oaxaca, and CHI: Chiapas.

\section{Datasets}

The best-track dataset for TCs in the eastern Pacific basin, compiled by the United States National Hurricane Center (NHC, 2011), is used in this analysis. This dataset is known to provide reliable estimates of circulation center position and maximum wind speed estimates during the entire TC life cycle. The intensity is classified within one of the following stages: tropical depression (sustained wind $<17 \mathrm{~m} / \mathrm{s})$, tropical storm $(17-32 \mathrm{~m} / \mathrm{s})$, and hurricane $(>32 \mathrm{~m} / \mathrm{s})$. Additionally, five hurricane categories are assigned according to the criteria defined by the Saffir-Simpson scale (e.g., Simpson, 2003).

Data on population impact was extracted from the Emergency Events Database (EM-DAT, http:// www.emdat.be), supported by the Université Catholique de Louvain in Belgium. This is a database that contains worldwide information on the occurrence and effects of natural disasters since 1900. These disasters are divided into several groups and TCs are part of the meteorological group. The raw information is compiled from various sources, including the United Nations, government organizations, insurance companies, research institutions and press agencies. The disasters are entered into the database if at least one of four criteria is fulfilled: (1) 10 or more people reported killed, (2) 100 or more people reported affected, (3) a declaration of state of emergency, or (4) a call for international assistance. Affected individuals are those who require immediate assistance and this may include injured, displaced, evacuated, or homeless people.

The Oceanic El Niño Index (ONI) was chosen to identify the phases of the El Niño/Southern Oscillation (ENSO) phenomenon. El Niño and La Niña episodes are based on a threshold of $\pm 0.5^{\circ} \mathrm{C}$ for the $\mathrm{ONI}$, which is defined as the three month running mean of sea surface temperature anomalies in the El Niño 3.4 region $\left(5^{\circ} \mathrm{N}-5^{\circ} \mathrm{S}, 120-170^{\circ} \mathrm{W}\right)$. It is calculated with respect to the 1971-2000 base period and, for historical purposes, El Niño and La Niña episodes are defined when the threshold is met for a minimum of five consecutive overlapping seasons. The ONI is available online at http://www.cpc.ncep.noaa.gov/products/analysis_monitoring/ensostuff/ensoyears.shtml. 
To determine the spatial coverage and intensity patterns of selected precipitation episodes, we used records from the ground-based network of rain gauges managed by Mexico's Servicio Meteorológico Nacional (SMN). Daily records are available from more than 3000 stations throughout the whole country, and selected three-day periods associated with landfalling TCs are analyzed. In order to set a climatological reference, records from the period 1951-2010 are examined and compared against accumulations derived from the selected group of TCs.

The three-dimensional structure of the atmospheric environment associated with selected cases is derived from gridded data issued by the National Centers for Environmental Prediction/National Center for Atmospheric Research (NCEP/NCAR; Kalnay et al., 1996) reanalysis project. This product has a horizontal resolution of approximately $2.5 \times 2.5$ degrees, which implies that the data are able to resolve large-scale circulations, but it provides a limited representation of the TC internal structure. Two-dimensional plots are made to identify relevant circulations within the atmosphere over North America as well as the eastern Pacific and western Atlantic oceans. These plots include fields used in a composite mode to identify properties of the tropospheric flow as well as ocean temperatures and convective parameters.

\section{Results}

We used EM-DAT to identify disasters associated with TCs making landfall in Mexico during the period 1970-2010. Examination of the database reveals that, during such period, a total of 52 TCs were reported to cause disasters and 60\% (31) of them affected the west coast. Almost two million people were affected and over 1700 killed. Recall that injured, displaced, evacuated or homeless people are considered to be affected. Localized heavy rainfall, flooding or landslides are reported with some of these events. The corresponding TCs were first taken from the EM-DAT records but we also used the NHC best track to confirm the storm development and add meteorological information while approaching the continent. If TCs are not consistent between EM-DAT and NHC datasets, the corresponding events are removed from the list of cases linked with disasters.

We ranked the 31 disasters of the west coast by using the number of affected people and the top 10 events were chosen for further analysis. Table I lists the corresponding top-10 TCs which, individually, resulted in counts from 20000 (Paul in 2006) to more than 800000 people affected (Pauline in 1997). As a result, more than 1.5 million people were affected and over 1300 killed, which correspond to 95 and $85 \%$ of the west coast totals, respectively. Best-track positions from these TCs are shown in Figure 3. Note that nine of them developed near the Gulf of California mouth to directly affect the states of Sinaloa, Sonora, or BCS and only one TC affected southern Mexico. In 1993, there were a couple of unique situations in which Lidia reached Texas 18 hours after landfall in Sinaloa, while Calvin first hit Jalisco and returned to the ocean to make a second landfall in southern BCS. Additionally, Table I provides more detailed information including landfall intensity and date, and most events are found to be from the latter part of the season (September or October).

Figure 4 displays the wind speeds of the selected TCs, which aids to identify peak intensity from 6 to 72 hours prior to landfall. Subsequent changes occurred while moving over land and led to weakening and dissipation, which may be explained by the lack of air-sea interactions and frictional effects by the presence of mountainous terrain. Four of these cyclones reached intensity between 58 and $69 \mathrm{~m} / \mathrm{s}$ (category 4 hurricane) over open water; however, during landfall, this was limited to the range $12-60 \mathrm{~m} / \mathrm{s}$ and the stronger circulations were associated with category 3 
Table I. Top 10 damaging tropical cyclones making landfall in western Mexico from 1970 through 2010. Events are ranked according to the affected population with 1 being the highest. El Niño, neutral or La Niña phases are indicated according to a five-month period centered on the landfall month.

\begin{tabular}{|c|c|c|c|c|c|c|c|}
\hline \multirow[t]{2}{*}{ Rank } & \multirow[t]{2}{*}{ Year } & \multirow{2}{*}{$\begin{array}{c}\mathrm{TC} \\
\text { name }\end{array}$} & \multicolumn{2}{|c|}{ Landfall } & \multicolumn{2}{|c|}{ Inhabitants } & \multirow[t]{2}{*}{ ENSO phase } \\
\hline & & & Intensity & Date & Affected & Killed & \\
\hline 1 & 1997 & Pauline & $\mathrm{H} 2$ & Oct 8 & 800200 & 230 & $\mathrm{EN}^{*}$ \\
\hline 2 & 1976 & Liza & H3 & Oct 1 & 276400 & 600 & $\mathrm{EN}$ \\
\hline 3 & 2006 & Lane & H3 & Sep 16 & 240700 & 4 & $\mathrm{EN}$ \\
\hline 4 & 2009 & Jimena & $\mathrm{H} 2$ & Sep 02 & 72000 & 4 & EN \\
\hline 5 & 1982 & Paul & $\mathrm{H} 2$ & Sep 30 & 50000 & 225 & $\mathrm{EN}^{*}$ \\
\hline 6 & 1995 & Ismael & H1 & Sep 15 & 40000 & 105 & LN \\
\hline 7 & 1993 & Calvin & $\mathrm{H} 2$ & Jul 7 & 34000 & 30 & $\mathrm{~N}$ \\
\hline 8 & 1993 & Lidia & $\mathrm{H} 2$ & Sep 13 & 30000 & 1 & $\mathrm{~N}$ \\
\hline 9 & 1983 & Tico & H3 & Oct 19 & 25000 & 135 & $\mathrm{~N}$ \\
\hline 10 & 2006 & Paul & TD & Oct 26 & 20000 & 4 & EN \\
\hline Total & & & & & 1588300 & 1338 & \\
\hline
\end{tabular}

TD: tropical depression; TS: tropical storm; HN: hurricane category ( $\mathrm{N}$ denotes hurricane category in the Saffir-Simpson scale); EN: El Niño; N: neutral; LN: La Niña; EN*: relatively strong EN phase.

hurricanes Liza (1976), Tico (1983), Pauline (1997), and Lane (2006). Over land, most of the TCs remained active for only 6-24 hours; however, Pauline lasted 36 hours inland close $(30-50 \mathrm{~km})$ to the coastline, while Jimena (2009) spent more than 72 hours over Baja California (Fig. 3a). Five category 4 hurricanes developed over open ocean but they were downgraded prior to landfall.

To determine some favorable conditions for the development of the top 10 TCs at landfall, we performed composites of several fields from the NCEP/NCAR reanalysis. We found that on average the top 10 TCs developed over near normal SST $\left(\sim 28 \pm 0.2^{\circ} \mathrm{C}\right)$ in the eastern Pacific, off the west coast of Mexico, while warmer conditions were observed in the eastern equatorial Pacific, typical of El Niño episodes; warm conditions are also observed at the entrance of the Gulf of California and to the west of the Baja California Peninsula (Fig. 5). In fact, the top five TCs occurred during E1 Niño phases and the last three TCs during neutral events (Table I). A single TC event cannot be attributed to an ENSO event because of the difference in the time scales of the two phenomena. However, when analyzing several extreme events, like in this analysis, it is useful to identify the background SST conditions, which may favor the development of TCs.

Warm SSTs at the entrance of the Gulf of California and to the west of Baja California (Fig. 5) may have favored northward extent of the tracks (up to 25-30 ${ }^{\circ} \mathrm{N}$ ) during TCs Liza (1976), Lane (2006), and Jimena (2009). Ismael (1995) and Tico (1983) also had a long displacement over the continent, but they occurred during La Niña and neutral years, respectively. Additionally, the midlevel geopotential heights (not shown) had an anti-cyclonic circulation over the Gulf of Mexico and most of Mexico, and a trough over the southwestern United States, which favored TC motion parallel to the west coast. The trough is associated with strong westerlies, dry air, and a component of the steering flow into northwestern Mexico. These facts are useful to understand the paths shown in Figure 3 as well as the tendency for northward or recurving tracks.

The convective structure of the selected group of TCs was examined through the outgoing longwave radiation (OLR). This parameter is used to distinguish enhanced convection associated with well-organized circulations over the tropics (Liebmann and Smith, 1996). During the landfall day, 


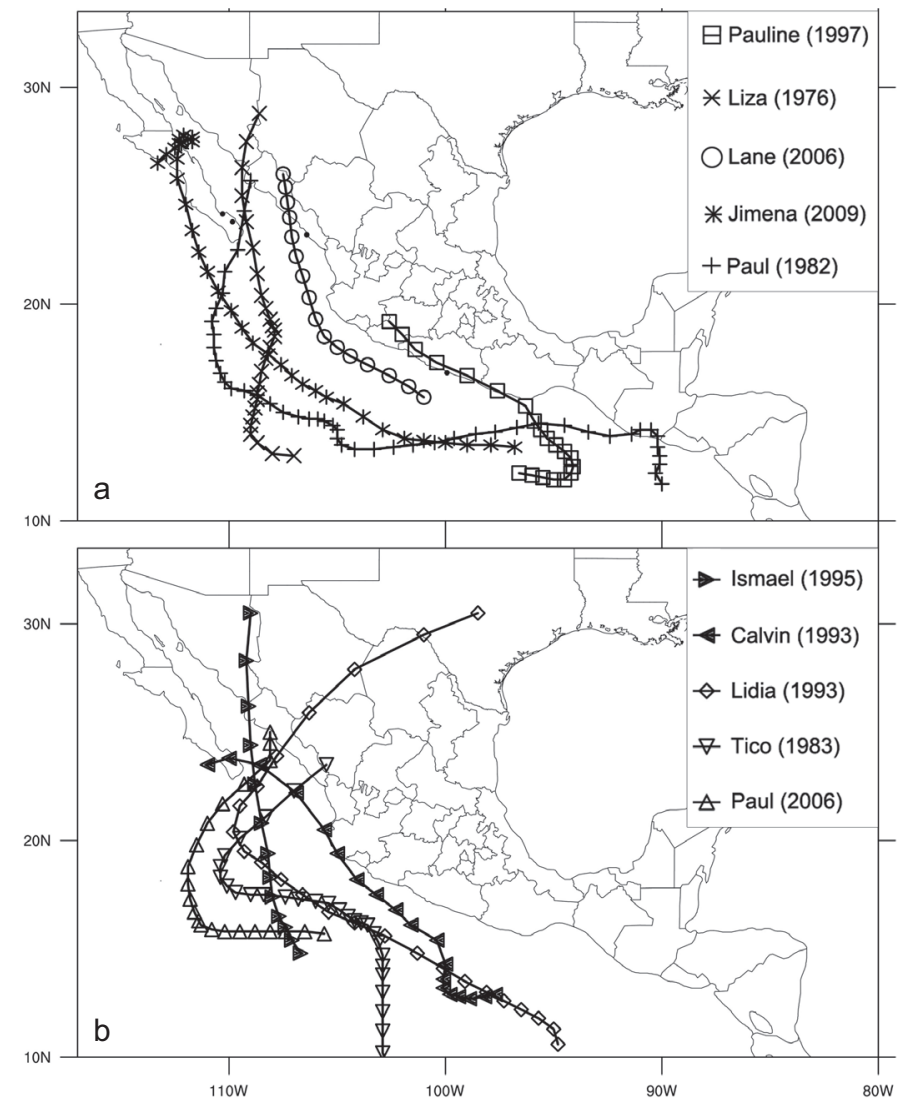

Fig. 3. Tracks of 10 tropical cyclones that made landfall in Mexico during the period 1970-2010 and caused large damage to the population. Data are taken from the National Hurricane Center database and positions are updated every six hours.

most of the selected TCs had convection in a radius within $300 \mathrm{~km}$ around from the circulation center and only one case (Paul in 1982; Fig. 6e) had a well-defined eye in the corresponding satellite image. The OLR distribution shown in Figure 6 has minimum values in the range of $120-160 \mathrm{~W} / \mathrm{m}^{2}$, near the TC circulation center, and larger $\left(200-220 \mathrm{~W} / \mathrm{m}^{2}\right)$ OLR is observed in the TCs with more limited impact such as Lidia in 1993 and Tico in 1983. Another feature of interest is the Inter Tropical Convergence Zone (ITCZ) being represented as an elongated band south of Mexico and bounded by $5-15^{\circ} \mathrm{N}$, which, in most cases, has active segments located south of the landfall site. The convection was also active in Central America, a vulnerable region to weather systems that provide heavy rainfall. In contrast, the Gulf of Mexico and the southwestern United States tend to be clear of convection, which is a feature consistent with mid-level anticyclones over the gulf and a mid-latitude environment propagating into North America.

In the following subsection, we provide a brief overview of the three events with the largest values of affected population: Pauline (1997), Liza (1976), and Lane (2006). These cases are 
chosen because of the large damage documented in Table I and because they are, also, considered to be representative of strong events that impacted areas with different population densities such as southern Mexico (Guerrero) and a couple of sites in the northwest, one in the mainland (Sinaloa) and another in BCS.

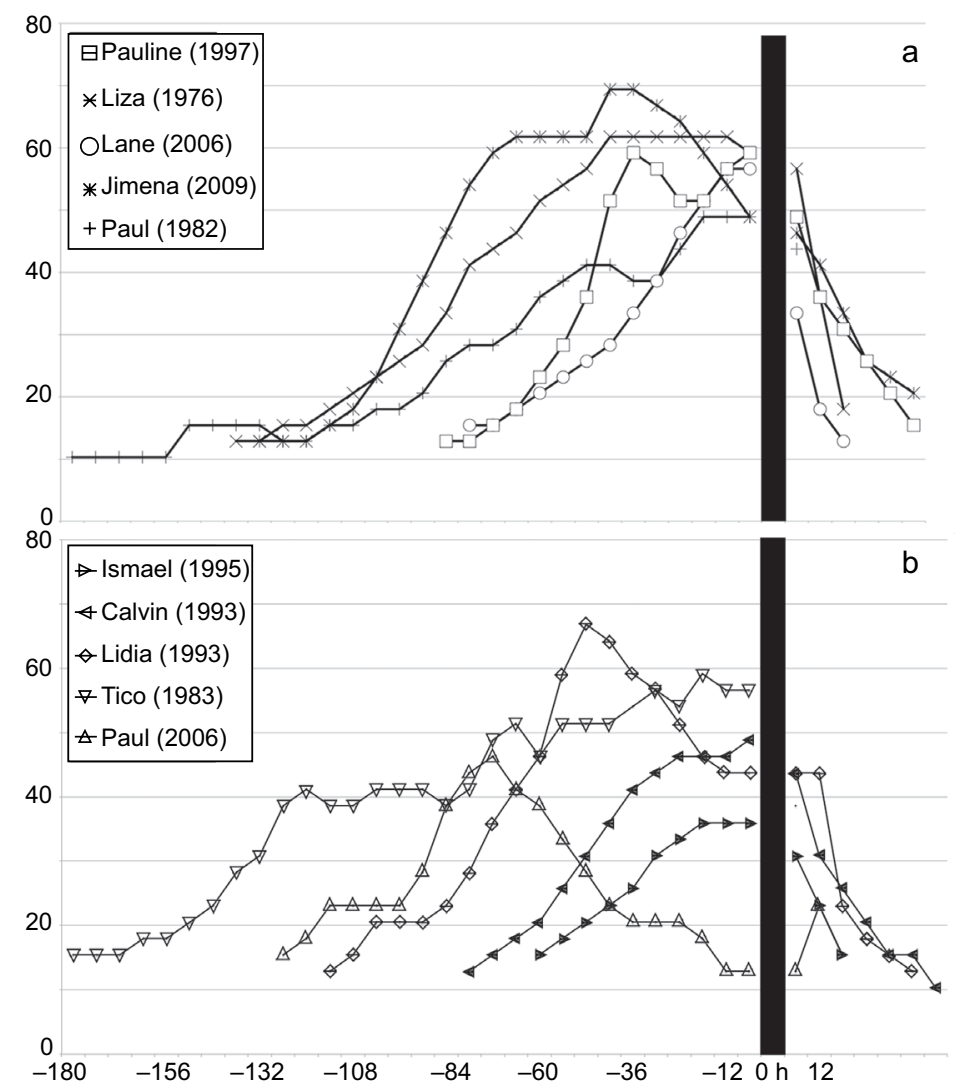

Fig. 4. Intensity ( $\mathrm{m} / \mathrm{s}$, vertical axis) from tropical cyclones that made landfall in the Pacific coast of Mexico. The horizontal axis represents six-hourly intervals and the black bar $(0 \mathrm{~h})$ indicates landfall with subsequent (right of the bar, positive) intervals representing positions over land. Intervals located to the left of the bar (negative) are prior to landfall.

\subsection{Hurricane Pauline (1997)}

According to EM-DAT (Table I), Pauline was responsible for more than 800000 affected inhabitants and its landfall is associated with the worst TC disaster ever experienced in the entire west coast of Mexico since 1951. Bitrán Bitrán (2001) reported that Pauline was responsible for 228 deaths, 35\% of them in the state of Oaxaca and 65\% in Guerrero, as well as damage estimated in \$448 million dollars. Most of the rainfall was collected within a single day and, according to Lawrence (1999), 

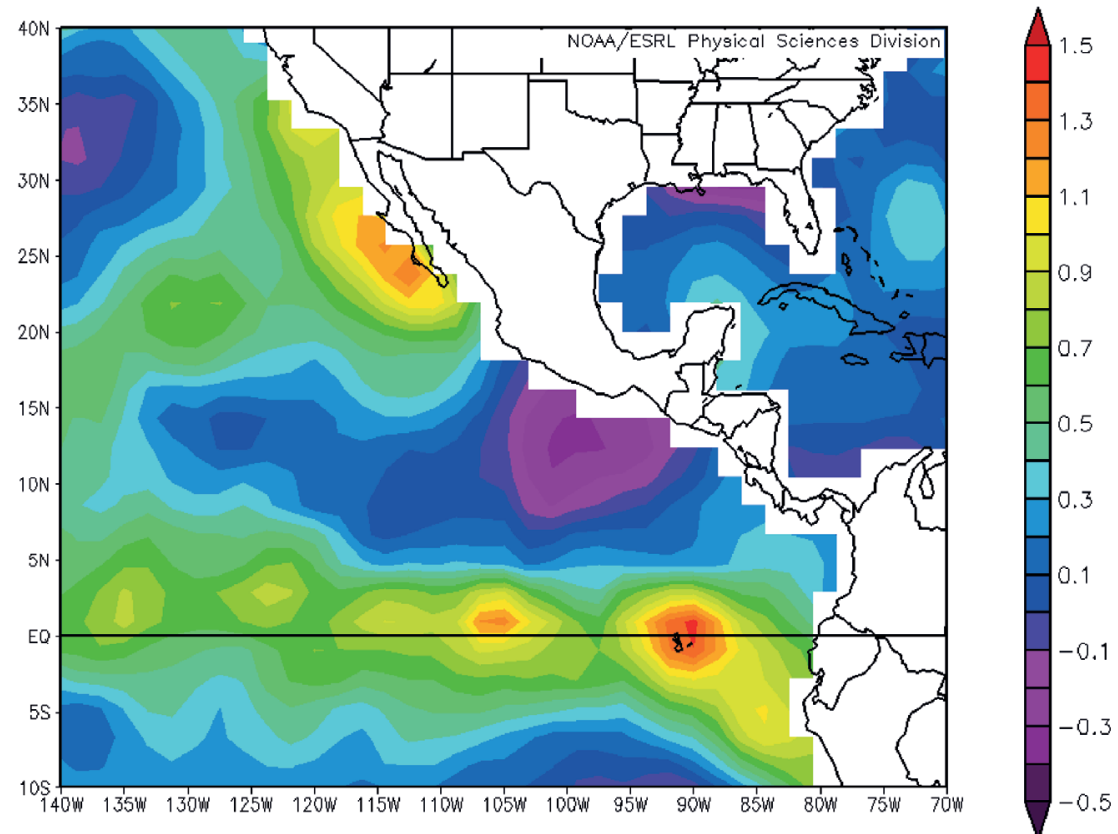

Fig. 5. Difference SSTs between the top 10 tropical cyclones reported in Table I and 21 events associated with 1970-2010 landfalls in the EM-DAT database. Data source is the NCEP/NCAR reanalysis and, for each event, individual times are taken 72 hours prior to landfall. The vertical bar represents scale of differences in ${ }^{\circ} \mathrm{C}$.

flooding occurred in many communities, one of them being Acapulco (see location in Fig. 8a). Information from INEGI's census indicates that Acapulco is the state's largest city and, in 1995, comprised $20 \%$ of the state population ( 2.9 million). As a result of the TC core moving along the coast, Oaxaca and Guerrero reported single-station rainfall up to 371 and $423 \mathrm{~mm}$, respectively.

To provide an overview of Pauline's convective structure before, during, and after landfall we examined infrared imagery from the Geostationary Operational Environmental Satellite (GOES). This is applied because of the satellite capability to measure cloud-top temperatures and, therefore, convective strength. Images are shown at maximum intensity over the ocean (Fig. 7a), at landfall (Fig.7b) and from subsequent positions (Fig. 7c-f). Our examination applies $4 \mathrm{~km}$ resolution and one-hour frequency imagery to determine pixels colder than $-60{ }^{\circ} \mathrm{C}$; such areas are useful to outline the core of intense hurricanes (e.g., Zehr and Knaff, 2007). During Pauline's evolution, areas with these temperatures covered portions of western Oaxaca and most of Guerrero, with some cells reaching values less than $-85^{\circ} \mathrm{C}$ (white pixels in Fig. 7b-7f) over the Sierra Madre del Sur foothills close to coastline. Other element to take into account is the relatively high elevation of the tropopause, derived from the Acapulco upper-air sounding at 0000 UTC October 9, which was estimated to be at $16760 \mathrm{~m}$ and $-86^{\circ} \mathrm{C}$ (not shown). In addition, this sounding had a strongly unstable environment (lifted index $=-4.6^{\circ} \mathrm{C}$ and CAPE $=2644 \mathrm{~J} / \mathrm{kg}$ ) suggesting that the thermodynamic conditions were favorable for ascending motion, which with topographic interaction resulted in intense updrafts during the TC landfall. 

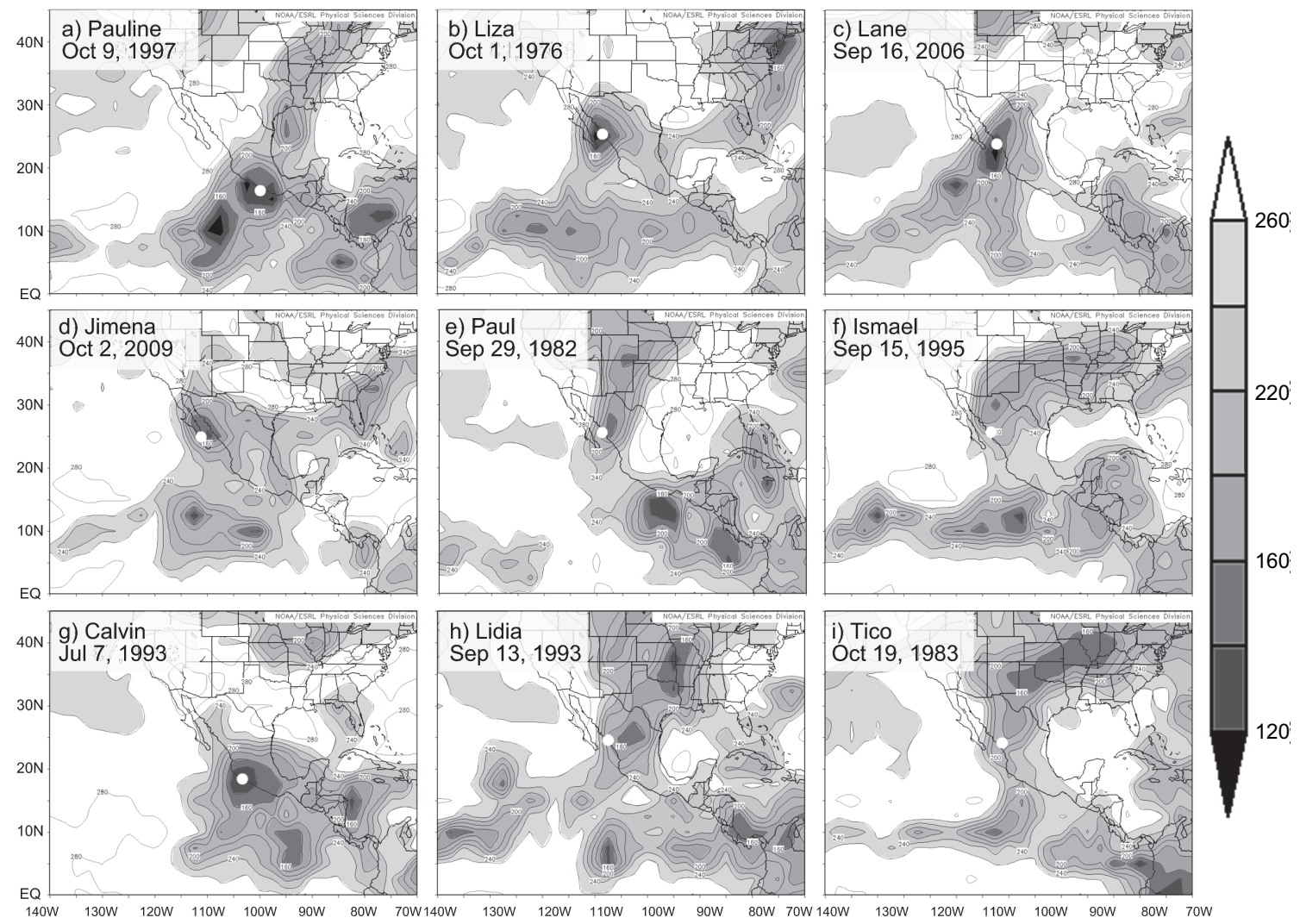

Fig. 6. Daily average of outgoing long-wave radiation (OLR) associated with nine of the 10 most damaging tropical cyclones making landfall along the Pacific coast of Mexico. Data source is the NCEP/NCAR reanalysis and the contour interval is $10 \mathrm{~W} / \mathrm{m}^{2}$. The vertical, right-side bar displays the corresponding scale in the range from 120 through $260 \mathrm{~W} / \mathrm{m}^{2}$. White dots represent landfall positions estimated by the National Hurricane Center.

A representation of the three-day rainfall from Pauline's passage, based on the SMN network, is shown in Figure 8a. Three-day accumulations reveal a distinct area around the TC track and north of the coast, in the eastern edge of the Sierra Madre del Sur. Heavy precipitation, with a distinct maximum of $485 \mathrm{~mm}$, depicts a pattern consistent with the large area of deep convection from satellite (Fig. 7). The maximum came from a site located $25 \mathrm{~km}$ away from the coastline, in the eastern Guerrero foothills, and a couple of additional stations with 300-400 mm accumulations are located around Acapulco. Inspection of daily records reveals that up to $360 \mathrm{~mm}$ were collected on October 8 (Fig. 8b). Stations, within $25 \mathrm{~km}$ from Acapulco, reported totals between 200-345 mm and some of them resulted in new records of daily and monthly rainfall since 1972. Within the impact area, $200 \mathrm{~km}$ away from the coastline, Guerrero had 27 out of the 160 available stations setting new records of daily rainfall during Pauline's passage, while only 17 (out of 105) stations set new records in Oaxaca and none in Michoacán. To provide a long-term perspective, Fig. 8c shows a time series of Acapulco's monthly precipitation. The plot displays the occurrence of 20 periods in which monthly accumulations exceeded $500 \mathrm{~mm}$. The largest amount is from August 1988, when a couple of tropical storms passing $300 \mathrm{~km}$ from the coast, and other convective systems, resulted 
in totals above $800 \mathrm{~mm}$. In October 1997, the monthly accumulation was $529 \mathrm{~mm}$ and $77 \%$ of this amount came from the three-day accumulation during Pauline's landfall. This evidence emphasizes the relevance of rainfall accumulations in the disaster's occurrence.

\subsection{Hurricane Liza (1976)}

Liza developed late in September and reached the southern Gulf of California, with category 4 strength, to make landfall in the border between Sinaloa and Sonora (Fig. 3a). Figure 9a shows a rainfall maximum of 300-400 mm in southeastern BCS and a secondary maximum (100-200 mm) around the landfall area, over the mainland. In a study for 1960-1979, Latorre and Penilla (1988) documented that Liza delivered the largest precipitation accumulation among $30 \mathrm{TCs}$ that affected BCS. Table II indicates that Liza was the 10th most intense TC during 1970-2010,
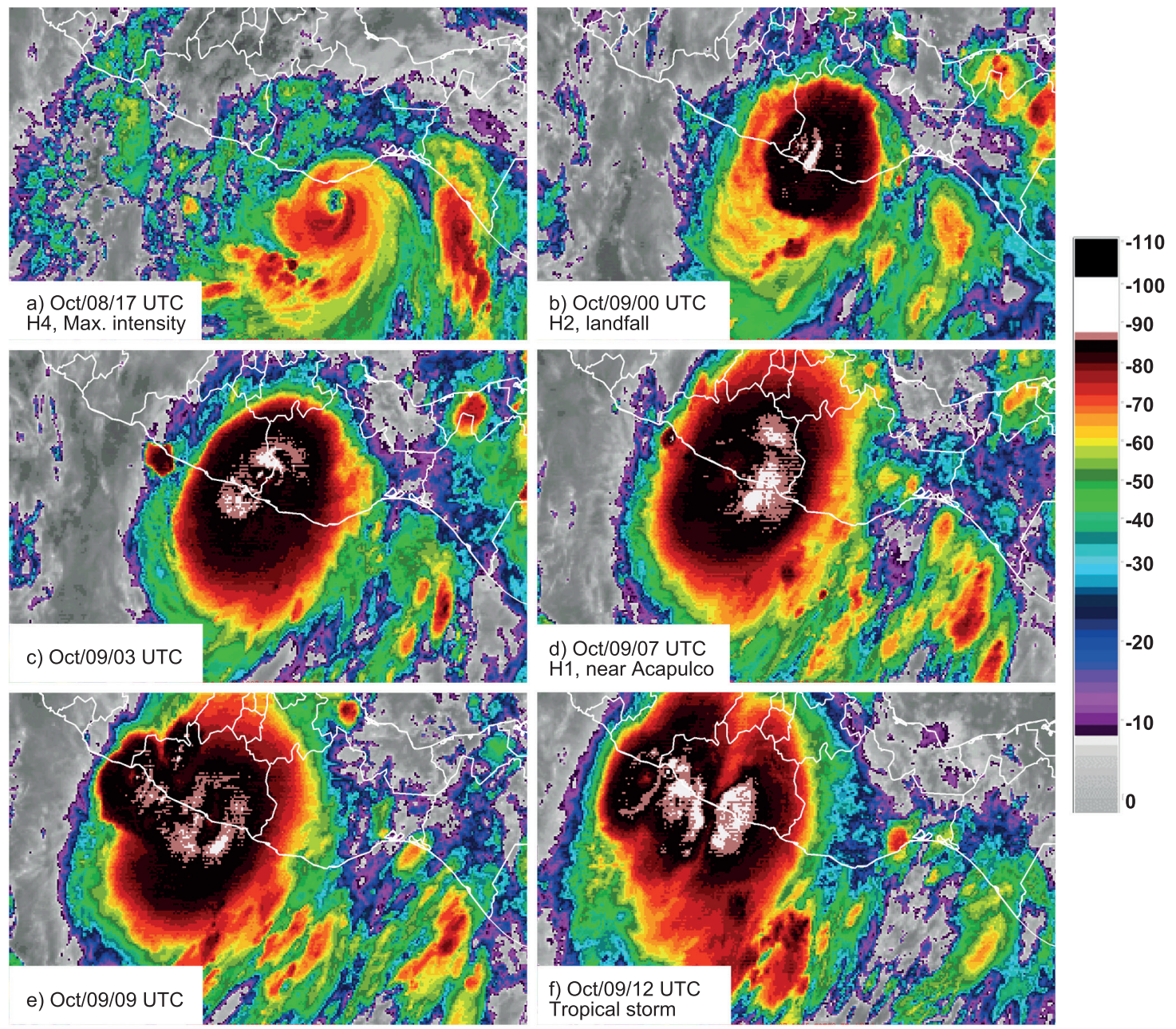

Fig. 7. GOES-8 infrared imagery for selected times prior to and after the landfall of tropical cyclone Pauline at 0000 UTC, October 9, 1997. The vertical bar indicates a calibrated scale of cloud-top temperatures $\left({ }^{\circ} \mathrm{C}\right)$. 

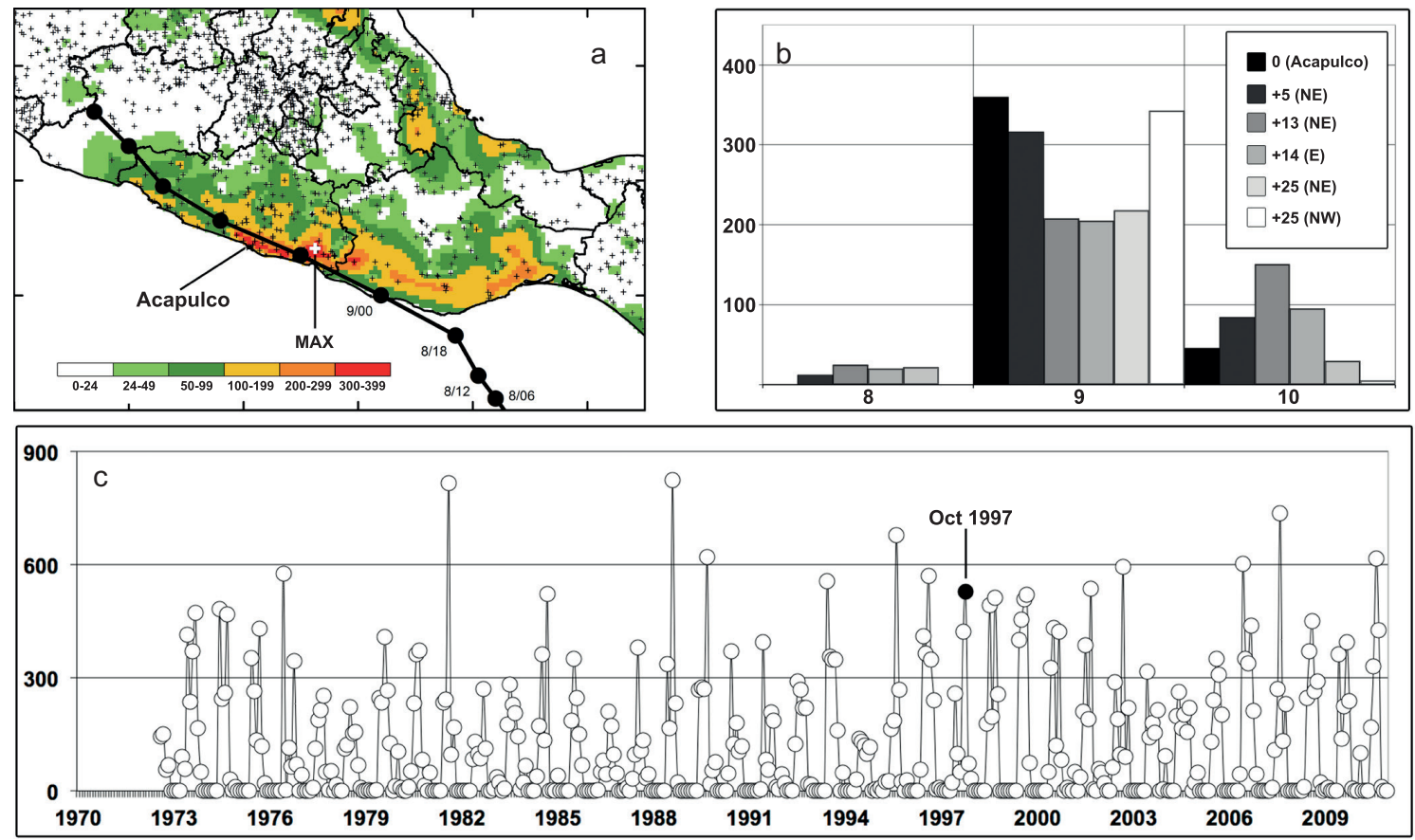

Fig. 8. (a) Rainfall accumulations (mm) during the period October 8-10, 1997, and tropical cyclone Pauline best-track positions indicated with the thick line. The location of the maximum amount (MAX) is provided and the plus signs are the available stations during the period. (b) Time series of daily rainfall $(\mathrm{mm})$ in stations at and close to Acapulco, Guerrero, for the period October 8-10. The distance $(\mathrm{km})$ and direction with respect to Acapulco is displayed in the upper-right insert. (c) Acapulco's monthly rainfall (mm) from 1970 through 2010. The black dot represents the accumulation during October 1997.

based on rainfall accumulations. An inspection of daily data at the BCS station with the largest precipitation, associated with Liza's passage, reveals a $425 \mathrm{~mm}$ total received in a single 24-hour period(Table II). Other maximum rates in the range of $210-320 \mathrm{~mm} / \mathrm{d}$ resulted in new records of precipitation, relative to the 1970s decade, along the eastern side of the Sierra de la Laguna. This is a mountain range located at the southern part of the peninsula (23-24 ${ }^{\circ} \mathrm{N}$, Fig. 1a) with mean elevations above $500 \mathrm{~m}$ asl, and highest elevations between 1500 and $2000 \mathrm{~m}$.

As a result of the circulation center's close approach to the peninsula, the capital of BCS (La Paz) was subjected to a tragic situation partially due to heavy rainfall. This city is located in a valley close to the Gulf of California and in 1976 had a population of roughly 70000 inhabitants. Flash flooding occurred due to failure of an earth-fill dam, and this lead to at least 435 deaths (Gunther, 1977). In the EM-DAT database, this event resulted in 600 killed and 276400 affected (Table I). This is, so far, the worst disaster in the state's history (Villanueva González, 2004) in terms of deaths and property damage. Time series of daily and monthly precipitation (not shown for the sake of brevity) were also constructed; they indicate a $296 \mathrm{~mm}$ peak in September 1976 that originated from $137 \mathrm{~mm}$ in a single day plus four previous days with individual contributions from 30-40 mm. Six years later, this record was practically tied by the approach of TC Paul (1982) that provided a rate of $136 \mathrm{~mm} / \mathrm{d}$ and $169 \mathrm{~mm}$ in total accumulation. However, this case did not 
lead to another disaster in La Paz and most of the damage was to the population and agricultural activities in Sinaloa (Gunther et al., 1983).

\subsection{Hurricane Lane (2006)}

Lane followed a track close to the coast (Fig. 3a) and made landfall over Sinaloa. Large-scale conditions, that favored this motion across the Sierra Madre Occidental, involved a mid-latitude trough in the western United States and an anticyclone located over eastern Mexico (Farfán et al., 2012). Gridded precipitation (Fig. 9b) shows maxima above $200 \mathrm{~mm}$ between 23 and $25^{\circ} \mathrm{N}$ and most of this precipitation fell in a couple of days, while the circulation center was approaching the coast. Examination of GOES imagery (not shown) suggests that the area of deep convection had limited extent and dissipation within 18-24 hours after landfall. During the 12 hours prior to landfall, the highest cloud tops were between -75 and $-80{ }^{\circ} \mathrm{C}$, and these areas were located over the ocean in the western flank of the low-level circulation. This fact is consistent with rapid intensification prior to landfall (Fig. 4a). Localized damage was reported from portions of Sinaloa; for example, Pasch et al. (2009) state that strong winds, floods and mudslides occurred in several communities as well as extensive damage to the communications and agriculture industry.
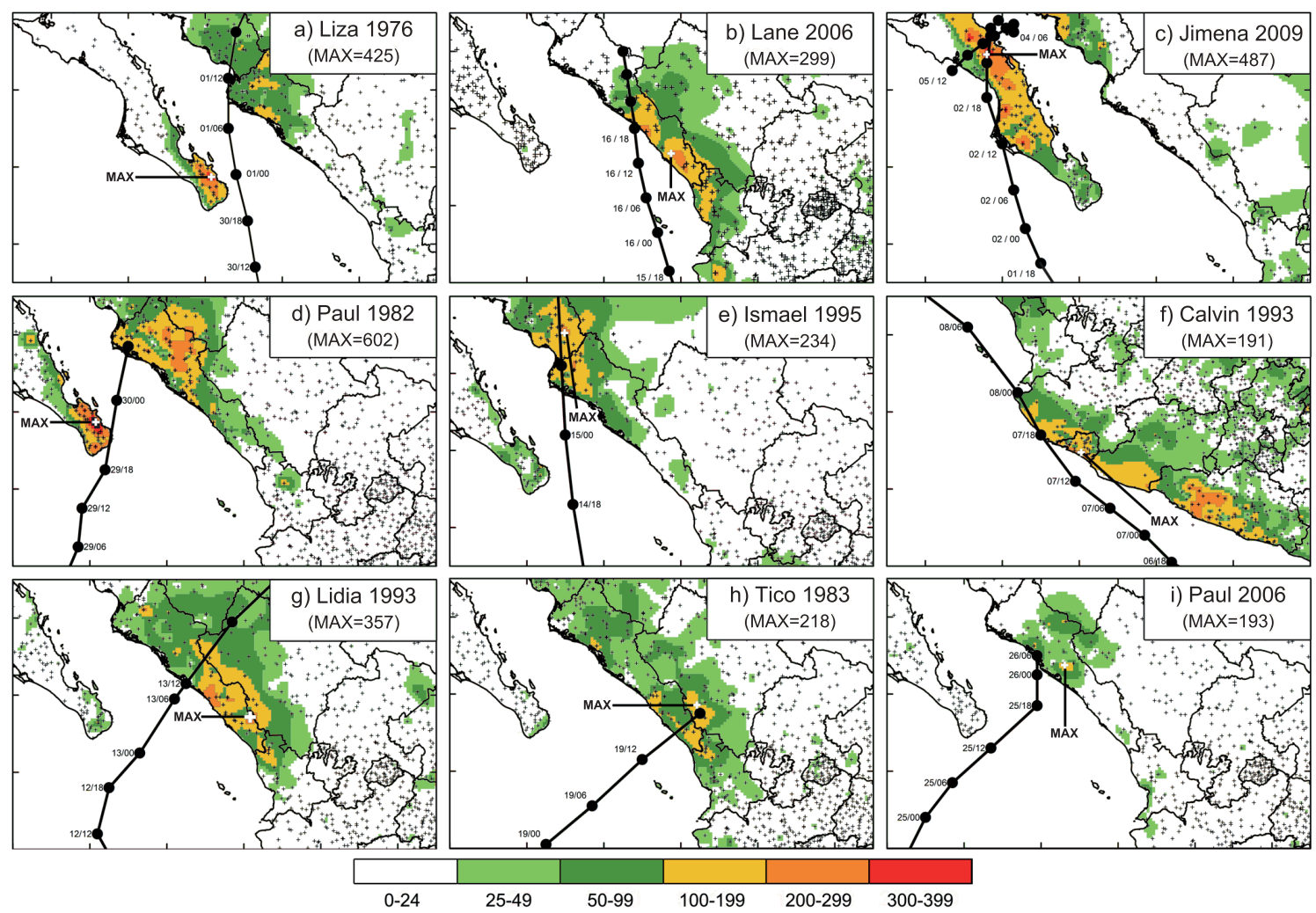

Fig. 9. Rainfall accumulations ( $\mathrm{mm}$ ) from nine of the 10 most damaging tropical cyclones making landfall in Mexico. Accumulations are from three days and centered on the day of landfall. The data is extracted from SMN observations (black plus signs). Maxima are indicated with the MAX label. Best-track positions are indicated with a black, thick line and dots at six-hourly intervals. 
According to INEGI, in 2005, Mazatlán was Sinaloa's second largest city and had a population of 352000 inhabitants. Lane was associated with a $223 \mathrm{~mm} / \mathrm{d}$ maximum, in a station $20 \mathrm{~km}$ northeast of the urban area; this is the second largest daily rate since the station became operational in 1966 . The largest rate $(320 \mathrm{~mm} / \mathrm{d})$ occurred during the arrival of hurricane Naomi in September 1968. To provide a historical perspective, we analyzed other relatively strong TCs that also made landfall in Sinaloa during the period 1970-2005. Tico (1983; Fig. 3b) arrived as a category 3 hurricane and was responsible for deaths, sunken ships, and extensive flooding in Mazatlán (Gunther and Cross, 1985). It is related to only 25000 affected and, in our analysis, this event had a $200 \mathrm{~mm} / \mathrm{d}$ maximum (Table II). With the same strength, hurricane Olivia (1975) passed just south of Mazatlán to provide significant property damage and impact to the population (Baum, 1976). This storm crossed Sinaloa in a matter of six hours and left 150-180 mm along the Sierra Madre Occidental foothills. The EM-DAT database documents 29 deaths but does not give an estimate of affected people. In contrast, Ismael (1995; Fig. 3b) was a category 2

Table II. Top 25 tropical cyclones making landfall in western Mexico from 1970 through 2010. Events are ranked according to the maximum rainfall accumulation, from meteorological stations in the landfall state, during the period that includes day of landfall, one day prior and one day after. The top 10 TCs from Table I are highlighted in bold typography.

\begin{tabular}{|c|c|c|c|c|c|c|c|}
\hline \multirow[t]{2}{*}{ Rank } & \multirow[t]{2}{*}{ Year } & \multirow[t]{2}{*}{ Name } & \multicolumn{2}{|c|}{ Landfall } & \multirow{2}{*}{$\begin{array}{l}\text { Rainfall total } \\
(\mathrm{mm})\end{array}$} & \multirow{2}{*}{$\begin{array}{l}\text { Max. rainfall } \\
\text { rate }(\mathrm{mm} / \mathrm{d})\end{array}$} & \multirow{2}{*}{$\begin{array}{l}\text { ENSC } \\
\text { phase }\end{array}$} \\
\hline & & & Intensity & State ${ }^{\S}$ & & & \\
\hline 1 & 2001 & Juliette & TS & $\mathrm{BCS}$ & 677 & $387 *$ & $\mathrm{~N}$ \\
\hline 2 & 1998 & Isis & TS & $\mathrm{BCS}$ & 610 & $360 *$ & LN \\
\hline 3 & 1982 & Paul & H3 & BCS & 602 & 305 & EN \\
\hline 4 & 2006 & John & $\mathrm{H} 2$ & BCS & 488 & $449 *$ & EN \\
\hline 5 & 2009 & Jimena & H2 & BCS & 487 & $440 *$ & EN \\
\hline 6 & 2003 & Marty & $\mathrm{H} 2$ & BCS & 483 & $323^{*}$ & $\mathrm{~N}$ \\
\hline 7 & 1996 & Fausto & H1 & $\mathrm{BCS}$ & 467 & 411 & $\mathrm{~N}$ \\
\hline 8 & 1981 & Lidia & TS & BCS & 446 & 323 & $\mathrm{~N}$ \\
\hline 9 & 2003 & Ignacio & H1 & BCS & 444 & 364 & $\mathrm{~N}$ \\
\hline 10 & 1976 & Liza & H3 & BCS & 425 & 425 & EN \\
\hline 11 & 1997 & Pauline & H2 & OAX & 423 & $360 *$ & EN \\
\hline 12 & 2000 & Norman & TD & $\mathrm{MIC}$ & 396 & $226^{*}$ & $\mathrm{LN}$ \\
\hline 13 & 2002 & Julio & $\mathrm{TS}$ & MIC & 391 & 185 & EN \\
\hline 14 & 1993 & Lidia & H2 & SIN & 357 & 320* & $\mathbf{N}$ \\
\hline 15 & 2002 & Kenna & $\mathrm{H} 4$ & NAY & 260 & $232 *$ & EN \\
\hline 16 & 1995 & Henriette & $\mathrm{H} 2$ & BCS & 339 & 221 & LN \\
\hline 17 & 1996 & Alma & $\mathrm{H} 2$ & MIC & 338 & $280^{*}$ & $\mathrm{~N}$ \\
\hline 18 & 1997 & Olaf & TD & OAX & 301 & 171 & EN \\
\hline 19 & 2006 & Lane & H3 & SIN & 299 & 223 & EN \\
\hline 20 & 1993 & Beatriz & $\mathrm{TS}$ & OAX & 288 & $217 *$ & $\mathrm{~N}$ \\
\hline 21 & 2006 & Paul & TD & SIN & 287 & 178 & EN \\
\hline 22 & 1992 & Lester & H1 & $\mathrm{BCS}$ & 281 & $227 *$ & $\mathrm{~N}$ \\
\hline 23 & 1995 & Ismael & H1 & SIN & 259 & 208* & $\mathbf{N}$ \\
\hline 24 & 1983 & Tico & H3 & SIN & 200 & 200 & $\mathbf{L N}$ \\
\hline 25 & 1993 & Calvin & H2 & JAL & 191 & 186 & $\mathbf{N}$ \\
\hline
\end{tabular}

* New maximum record with respect to the period 1951-2010.

$\S$ State abbreviations use the same notation as in Fig. 2. 
hurricane that provided larger rainfall rates (up to $234 \mathrm{~mm}$ ) to result in counts of 105 deaths and 40000 affected.

\section{Discussion}

The previous section provided information on the damage caused by eastern Pacific TCs moving across the coast of Mexico. We documented the rainfall derived from the top 25 landfall events that occurred between 1970 and 2010, but the main focus is on the top 10 TCs according to the disaster intensity. By using the EM-DAT database, we restricted the analysis to the 10 most damaging events ranging from 20000 to more than 800000 affected people per event. Late in the 1997 season, Pauline produced extraordinary rainfall in Guerrero and Oaxaca to become the worst natural-related disaster in the west coast of Mexico. Liza (1976) caused a large number of deaths in Baja California Sur, while Lane (2006) was associated with moderate impact on Sinaloa.

By examining the selected TCs, we determined the following elements to be important with respect to the impact over coastal and inland areas.

\subsection{Spatial patterns around the track}

The spatial distribution of rainfall from the top10 TCs is shown in Figs. 8a and 9; these figures show that the rainfall maxima is located, on average, $65 \mathrm{~km}$ from the storm track, and maxima ranged from 25 to $211 \mathrm{~km}$ from the storm. Stations getting maximum rainfall are located at elevations ranging from $37 \mathrm{~m}$ close to the Colima coast (Fig. 9f) to $2570 \mathrm{~m}$ in Durango (Fig. 9h). Depending on the motion at landfall and the terrain-ocean configuration, the rain maxima tend to occur to the right for mainland landfalls, left of the storm track in BCS or very close to the circulation center. More detailed information of rainfall accumulations at single stations and TC tracks is available at http://redesclim.org.mx/datosclim/huracanes.php.

\subsection{Extraordinary rainfall rates exceeding previous records}

According to Table II, the corresponding rainfall values for the selected top $10 \mathrm{TCs}$ (from Table I) are in the range of 191-602 $\mathrm{mm}$ in total accumulations and $178-440 \mathrm{~mm} / \mathrm{d}$ for daily rates. Additional inspection allowed us to identify that 14 , out of the 25 , cases set at least one new record of daily maxima at single stations. In particular, two of the top 10 cases from Table I (Pauline in 1997 and Jimena in 2009) set more than 25 new records of daily rates in the landfall region. It is interesting to note that BCS is the state that has received the largest accumulation totals $(281-677 \mathrm{~mm})$ and rates $(221-449 \mathrm{~mm} / \mathrm{d})$, while most of these events occurred in September.

\subsection{Population density near landfall areas}

Even though there is relatively large rainfall associated with TC landfalls in BCS, this state has experienced limited impacts in terms of affected people due to its low population density. With exception of Liza's approach in 1976, most of the events resulted in a limited number of affected people and deaths. In contrast, TC passage close to highly populated urban areas such as Acapulco during Pauline (1997), along with relatively large rainfall rates resulted in strong impacts. Tropical 
cyclones Tico, 1983 (Gunther et al., 1983) and Lane, 2006 (Pasch et al., 2009) were also responsible for flooding and property damage in Mazatlán.

\subsection{Storm motion at landfall}

The time taken by the TCs to move close or across populated areas is an important element to consider in the assessment of the event's impact. The longer the exposure to strong winds and heavy rainfall, the more likely to experience damage. For example, weak steering flow resulted in very slow motion (1-2 m/s) prior to Juliette's landfall in 2001, and rainfall for a couple of days over southern BCS (Farfán, 2004). This situation resulted in the largest rainfall accumulation (677 mm, Table II) and 16 new records of maximum daily rates during the study period. However, this event is associated with only 3800 affected inhabitants and three deaths; thus, Juliette is not in the top 10 TCs shown in Table I. According to Fig. 9c, Jimena (2009) lasted more than 48 hours over land to cause 72000 affected people and four deaths in BCS. The rainfall maximum was just under $500 \mathrm{~mm}$ and $440 \mathrm{~mm} / \mathrm{d}$ to cause 30 new records, most of them in the central peninsula. On the other hand, fast-moving TCs (9-13 m/s: Tico in 1983, Lidia in 1993, Ismael in 1995, Fausto in 1996, and Kenna in 2002) are associated with low to medium rates $(200-411 \mathrm{~mm} / \mathrm{d})$ and accumulations (200-467 mm), along with a limited number of stations (1-9) setting up new rate records.

\subsection{Dependence on landfall intensity}

The damage to the population was not necessarily proportional to the intensity of the incoming TCs. For example, none of the top 10 cases were intense hurricanes (i.e., category 4 or 5) at landfall; however, most of them had category 2 or 3 strength that resulted in a wide range of affected population (30000-800000) and death toll (1-600). In contrast, only one category 1 hurricane (Ismael, 1995) occurred, which caused more damage. Kenna (2002) is the only category 4 hurricane that made landfall (Table II) but it is linked with 9000 affected people and three deaths. We believe that the diminished impact may be due, in part, to its fast motion at landfall $(11 \mathrm{~m} / \mathrm{s})$.

\subsection{The ENSO phase}

It is interesting to notice that TCs associated with the top five disasters occurred during the warm El Niño phases of 1997, 1976, 2006, 2009 and 1982, as indicated in Table I. The lower impact disasters occurred during La Niña (1995), neutral conditions (1983 and 1993), and El Niño (2006). The top 10 disasters analyzed in the study provide some evidence of a possible influence of El Niño events to produce favorable conditions to induce disasters in the Pacific coast. During El Niño, the vertical wind shear weakens in the Eastern Pacific favoring intensification (e.g., Bell and Chelliah, 2006) and the TCs tend to be longer-lived and more intense (e.g., Camargo and Sobel, 2005). Looking at the large-scale conditions that characterized the top 25 TCs providing largest rainfall, we found that 10 of the TCs occurred during El Niño, 10 during neutral conditions, and only five during La Niña. Thus, with the limited number of years of this study, it appears that a significant difference is that during La Niña there is a tendency for less TC-related disasters to occur than during El Niño or neutral years.

An outstanding aspect is that only five of the top 10 cases occurred during storm seasons considered more active than average in terms of named TCs in the eastern Pacific basin. The long- 
term average is 15-16 TCs (e.g., Blunden et al., 2011) and the seasons of 1982 (Paul), 1983 (Tico), 1997 (Pauline), 2006 (Lane) and 2009 (Jimena) exceeded the average from 1 to 5 TCs; interestingly, with the exception of 1983, all occurred during El Niño events. The remaining of the top 10 cases occurred during normal seasons or even during relatively inactive seasons such as 1995 (La Niña event), when Ismael developed. For operational applications this fact has an important implication because it allows evaluating possible impacts from an upcoming season.

\subsection{Information and early warnings}

Hurricane Liza, which developed during an El Niño event, deserves special attention because it was associated with 600 deaths (Table I), the largest number in the EM-DAT database for all of the Mexican coasts. La Paz was affected in a matter of few hours (Villanueva González, 2004) as flash flooding occurred in a localized area with a $137 \mathrm{~mm} / \mathrm{d}$ maximum rain rate. The flash flooding was partially natural but also due to a lack of early warning dissemination. At that time, there were forecasts regularly issued by the NHC but they were based on coarse models and the (GOES) satellite era was in the early stages. Therefore, limited information and lack of early warnings to the public played an important role during Liza's landfall. In contrast, during 20002010 less than 40 deaths have been reported from the landfall of moderate and strong hurricanes. This may be due, in part, to more reliable and promptly delivered forecasts to the population in high-risk areas as well as more effective actions performed by emergency managers at local and regional scales.

\subsection{Human development index}

Another element of relevance in determining the impact of an extreme TC event at landfall is the human development index (HDI), an estimate of the level of human's standard of living. The HDI is built upon United Nations guidance and takes into account health, education, and income. According to recent surveys from the Mexican government, the states of Guerrero, Oaxaca, and Chiapas are among the less developed states in the whole country. At a more detailed (municipal or local) level, the lowest indices are in the highlands of central Chiapas, eastern Guerrero, and western Oaxaca. This information can be used to better understand the large number of affected population and deaths from hurricane Pauline (1997) as it made landfall in Oaxaca and crossed over Guerrero. Therefore, strong winds and heavy rainfall occurred in under-developed (vulnerable) areas where the assistance from emergency managers was difficult to arrive prior and just after the TC passage.

\subsection{Comparison with the Atlantic basin}

During the period of interest, the EM-DAT database indicates that 19 TCs from the Atlantic basin made landfall in eastern Mexico. Almost 5 million people were affected and less than 600 were killed. Tropical cyclones Stan and Wilma, from the extremely active season of 2005 (Beven et al., 2008), are the most destructive storms of the study period as they were associated with almost two million affected and 33 killed. At landfall, Wilma was a category 4 hurricane while Stan was a category 1 hurricane; both provided large amounts of total rainfall $(>500 \mathrm{~mm})$ and established new records of daily rainfall $(>350 \mathrm{~mm} / \mathrm{d})$ at certain stations. At landfall, there were several 
category 5 hurricanes such as Gilbert, in 1988, which resulted in moderate amounts of rainfall (up to $340 \mathrm{~mm}$ in three days over Tamaulipas) as well as 100000 affected and 240 deaths. One interesting feature from many of the major Atlantic hurricanes is that they made a first landfall in the Yucatan Peninsula, and 24-48 hours later they made a second strike over the western Gulf of Mexico (Tamaulipas). This implies more extensive geographical area and coastal communities that can potentially be impacted by a single TC.

\section{Conclusion}

Based on maximum rainfall accumulations, we analyzed the TCs associated with disasters that made landfall on the Pacific coast during the period 1970-2010. From this group, we examined the 10 top TCs that caused major impacts on the population. Our results indicate that BCS, in northwestern Mexico, is the state that received most of the impacts due to heavy rainfall; TC Liza, in September 1976, was the worst landfall event, which caused 600 deaths in a single community. Sinaloa was the second most affected state while, practically, no direct impact occurred in Chiapas, Sonora, and Baja California. Pauline, late in the season of 1997, was responsible for more than 800000 affected inhabitants in Oaxaca and Guerrero; this is considered the worst TC-related disaster experienced in the entire west coast of Mexico since 1951. Knowledge of TC motion, wind intensity, and total rainfall accumulations are useful parameters that go along with the occurrence of property damage and loss of lives. However, our results suggest that there is a lack of a well-defined relationship between TC intensity at landfall and population impact. Therefore, the analysis of particular case studies should be performed on an individual basis to achieve more solid results. Environmental indices, such as the ENSO phase and the seasonal prediction of the total TC frequency are useful to outlook the likelihood of disasters. We found that the majority of the top 10 TC-related disasters occurred during El Niño events, followed by neutral conditions. Considering the top 25 TC-related extreme rainfall events, we found that El Niño and neutral conditions are more favorable for extreme events inducing to disasters than La Niña. Due to the predictable nature of the ENSO phases, it will be important to understand the thermo-dynamical differences between El Niño and neutral conditions as well as their relationship to TCs to better predict possible impacts on Mexico. Future research should include the examination of all the available observations from surface stations, satellites, and radars, as well as hydrometric measurements to better monitor episodes having a potential to become disasters.

\section{Acknowledgements}

This research study was partially supported by the ANUIES-CSUCA Program for International Cooperation, CONACyT through the REDESClim Network (LMF and TC), and IAI through the CRN-2050 grant (EJA). Alejandro González and Adolfo Portocarrero, from SMN, provided the rainfall records. Composite fields (Figs. 5, 6) were provided by the NOAA/ESRL Physical Sciences Division via http://www.esrl.noaa.gov/psd/data/composites/day/. The first author would like to thank Stephen V. Smith for valuable support and Ismael Villanueva for help to improve the figures. Two anonymous reviewers provided comments and suggestions that improved the manuscript. 


\section{References}

Baum R. A., 1976. Eastern North Pacific tropical cyclones of 1975. Mon. Wea. Rev. 104, 475-488.

Bell D. B. and M. Chelliah, 2006. Leading tropical modes associated with interannual and multidecadal fluctuations in North Atlantic hurricane activity. J. Climate 19, 590-612.

Beven J. L., L. A. Avila, E. S. Blake, D. P. Brown, J. L. Franklin, R. D. Knabb, R. J. Pasch, J. R. Rhome and S. R. Stewart, 2008. Atlantic hurricane season of 2005. Mon. Wea. Rev. 136, 1109-1173.

Bitrán Bitrán D., 2001. Características del impacto socioeconómico de los principales desastres ocurridos en México en el periodo 1980-1999. México: Cenapred, 107 pp.

Blunden J., D. S. Arndt and M. O. Baringer, 2011. State of the climate in 2010. Bull. Amer. Meteor. Soc. 92, S1-S236.

Camargo S. J. and A. H. Sobel, 2005. Western north Pacific tropical cyclone intensity and ENSO. J. Climate 18, 2996-3006.

Farfán L. M., 2004. Regional observations during the landfall of tropical cyclone Juliette (2001) in Baja California, Mexico. Mon. Wea. Rev. 132, 1575-1589.

Farfán L. M., R. Romero-Centeno and G. B. Raga, 2012. Observations and forecasts from the landfall of tropical cyclones John, Lane, and Paul (2006) over northwestern Mexico. Weather Forecast. 27, 1373-1393.

Gunther E. B., 1977. Eastern Pacific tropical cyclones of 1976. Mon. Wea. Rev. 105, 508-522.

Gunther E. B., R. L. Cross and R. A. Wagoner, 1983. Eastern North Pacific tropical cyclones of 1982. Mon. Wea. Rev. 111, 1080-1102.

Gunther E. B. and R. L. Cross, 1985. Eastern North Pacific tropical cyclones of 1984. Mon. Wea. Rev. 113, 1393-1410.

INEGI, 2011. Censo General de Población y Vivienda 2010. México, Instituto Nacional de Estadística, Geografía e Informática. [Available at: http://www.inegi.org.mx/est/contenidos/ proyectos/ccpv/default.aspx].

Jáuregui E., 2003. Climatology of landfalling hurricanes and tropical storms in Mexico. Atmósfera 16, 193-204.

Kalnay E., M. Kanamitsu, R. Kistler, W. Collins, D. Deaven, L Gandin, M. Iredell, S. Sana, G. White, J. Woollen, Y. Zhu, M. Chelliah, W. Ebisuzaki, W. Higgins, J. Janowiak, K. C. Mo, C. Ropelewski, J. Wang, A. Leetmaa, R. Reynolds, R. Jenne and D. Joseph, 1996. The NCEP/ NCAR 40-year reanalysis project. Bull. Amer. Meteor. Soc. 77, 437-471.

Latorre C. and L. Penilla, 1988. Influencia de los ciclones en la precipitación de Baja California Sur. Atmósfera 1, 99-112.

Lawrence M. B., 1999. Eastern North Pacific hurricane season of 1997. Mon. Wea. Rev. 127, 2440-2454.

Liebmann B. and C.A. Smith, 1996. Description of a complete (interpolated) outgoing longwave radiation dataset. Bull. Amer. Meteor. Soc. 77, 1275-1277.

Mosiño P. and E. García, 1974. The climate of Mexico. World Survey of Climatology. Vol. 11, Climates of North America (H. E. Landsberg, Ed.). Elsevier, 345-404.

NHC, 2011. Best track data (HURDAT). Eastern north Pacific tracks. [Available at: http://www. nhc.noaa.gov/data/hurdat/hurdat_nepac_1949-2011.txt].

Pasch R. J., E. S. Blake, L. A. Avila, J. L. Beven, D. P. Brown, J. L. Franklin, R. D. Knabb, M. M. Mainelli, J. R. Rhome and S. R. Stewart, 2009. Eastern North Pacific hurricane season of 2006. Mon. Wea. Rev. 137, 3-20. 
Simpson R., 2003. Communicating damage potentials and minimizing hurricane damage. In: Hurricane! Coping with disaster (R. Simpson, Ed.). Washington: American Geophysical Union, 155-164 (AGU Publications).

Villanueva González E. 2004. El ciclón Liza. Historia de los huracanes en BCS. La Paz, Mexico: Universidad Autónoma de Baja California Sur, 227 pp.

Zehr R. M. and J. A. Knaff, 2007. Atlantic major hurricanes, 1995-2005, characteristics based on best-track, aircraft, and IR images. J. Climate 20, 5865-5888. 